\begin{tabular}{|c|c|}
\hline SIL AMPARI & $\begin{array}{l}\text { PRINTED ISSN: } 2620-6919 \\
\text { ONLINE ISSN: } 2620-3316\end{array}$ \\
\hline $\begin{array}{l}\text { Published by LP4MK STKIP PGRI LUBUKLINGGAU } \\
\text { Prodi Pendidikan Bahasa Indonesia, STKIP PGRI Lubuklinggau, } \\
\text { South Sumatera, Indonesia }\end{array}$ & $\begin{array}{r}\text { Vol. 3, No. 2, } 2020 \\
\text { Page: } 440-451\end{array}$ \\
\hline
\end{tabular}

\title{
KEKERASAN TERHADAP PEREMPUAN DALAM NOVEL CINTA 2 KODI KARYA ASMA NADIA
}

\author{
Puspa Indah Utami \\ Universitas PGRI Palembang \\ Jalan Prof H. Hadari Nawawi, Palembang, Sumatera Selatan, Indonesia \\ Email: piutami2717@gmail.com
}

\begin{abstract}
Abstrak
Tujuan penelitian ini adalah untuk memperoleh pemahaman yang mendalam terhadap kekerasan perempuan dalam novel Cinta 2 Kodi karya Asma Nadia. Metode penelitian menggunakan metode analisis isi. Teknik pengumpulan data menggunakan teknik dokumentasi berupa novel Cinta 2 Kodi karya Asma Nadia. Data dalam penelitian ini adalah kata, frase, dan kalimat tentang kekerasan yang dialami oleh tokoh perempuan dalam novel Cinta 2 Kodi karya Asma Nadia. Teknik analisis data dengan cara tahap deskripsi data, reduksi data, seleksi data, dan interpretasi. Berdasarkan hasil penelitian ditemukan bentuk tindakan kekerasan psikis terhadap tokoh perempuan yaitu Aryani dan Kartika. Kekerasan psikis yang dilakukan oleh suami Aryani menyebabkan Aryani mengalami penyakit yang tidak terdeteksi akibat stres berkepanjangan. Tokoh Aryani dan Kartika memiliki sikap sabar, ikhlas, kerja keras, dan berani dalam menghadapi setiap ujian dalam hidupnya. Keunggulan dalam mengemas cerita dengan konflik berupa kekerasan psikis yang diterima tokoh perempuan dalam mencapai kesuksesan dan nilai karakter sabar, ikhlas, kerja keras, dan berani yang dihadirkan membuat novel ini layak dijadikan salah satu bahan bacaan sastra di tingkat sekolah dan perguruan tinggi.
\end{abstract}

Kata kunci: kekerasan, perempuan, novel

\section{VIOLENCE AGAINST WOMEN IN THE CINTA 2 KODI NOVEL BY ASMA NADIA}

\begin{abstract}
The purpose of this study was to gain a deep understanding of women's violence in in the Cinta 2 Kodi novel by Asma Nadia. The research method used content analysis method. The data collection technique used documentation techniques in the form of the Cinta 2 Kodi novel by Asma Nadia. The data in this study are words, phrases and sentences about violence experienced by female characters in the Cinta 2 Kodi novel by Asma Nadia. Data analysis techniques by means of the data description stage, data reduction, data selection, and interpretation. Based on the research results, it was found that the forms of psychological violence against female figures, namely Aryani and Kartika. The psychological violence perpetrated by Aryani's husband caused Aryani to experience an undetectable illness due to prolonged stress. The characters Aryani and Kartika have a patient, sincere, hard work and courage in facing every test in their life. The excellence in packaging stories with conflicts in the form of psychological violence received by female characters in achieving success and the values of patience, sincerity, hard work, and courage that are
\end{abstract}


presented make this novel worthy of being used as a literary reading material at the school and college level.

Keywords: violence, women, novel

\section{A. Pendahuluan}

Kekerasan adalah serangan terhadap fisik maupun integritas mental psikologi seseorang (Werdiningsih, 2016). Kekerasan terhadap sesama manusia pada dasarnya berasal dari berbagai sumber, salah satu kekerasan terhadap satu jenis kelamin tertentu yang disebabkan oleh anggapan gender (Fakih, 2013; Galistya, 2019). Kekerasan yang disebabkan oleh bias gender disebut genderrelated violence. Permasalahan mengenai kekerasan perempuan banyak dibicarakan pada pengarang Indonesia termasuk novel Cinta 2 Kodi karya Asma Nadia.

Djajanegara (2003) menyatakan dalam pandangan masyarakat patriarki tumbuh dan mengakar sebuah konsep bahwa perempuan yang ideal adalah perempuan yang harus rela mengalah. Sifat yang tercermin dari konsep itu adalah perempuan yang menjaga kesadaran serta kemurnian mereka, berpikir pasif, dan menyerah, serta rajin mengurus rumah tangga atau domestisitas. Menurut Lakoff dalam Santoso (2011) dan Rokhmansyah dkk., (2018), perempuan mempunyai cara berbicara yang berbeda dari laki-laki, yakni sebuah cara berbicara (way of speaking) yang merefleksikan dan menghasilkan posisi subordinat dalam masyarakat. Artinya, bahasa yang dihasilkan perempuan, secara sadar maupun bawah sadar, cermin dari posisi "yang dikuasai" atau "yang didominasi".

Kekerasan terhadap perempuan terjadi sebagai akibat dari hubungan kekuasaan langsung antara laki-laki dan perempuan, di mana laki-laki mempunyai kepentingan mendasar dan konkret untuk mengendalikan, menggunakan, dan menindas perempuan, yakni untuk melaksanakan dominasi (Fitriani, 2019; Febriany, 2016). Dominasi adalah setiap hubungan di mana pihak (individu atau kolektif) yang dominan berhasil membuat pihak lain (individu atau kolektif) yang disubordinasikan sebagai alat kemauannya dan menolak untuk mengakui kebebasan subjektivitas pihak yang disubordinasikan. Atau sebaliknya, dilihat dari 
sudut pandang pihak yang disubordinasikan hanyalah sebagai alat kemauan pihak yang dominan (Ritzer \& Goodman, 2012).

Karya sastra adalah hasil imajinasi pengarang yang berupa ungkapan pikiran dan perasaan yang dituangkan dalam suatu karya untuk menghayati kejadiankejadian yang ada di sekitarnya, baik yang dialami oleh pengarang maupun yang terjadi pada orang lain dan sekelompok masyarakat sehingga memberikan nilai dan manfaat kepada pembacanya (Noermanzah, 2017). Dalam sastra Indonesia, banyak penulis membuat sebuah karya yang membahas berbagai persoalan seperti, kekerasan, sosial, politik, ekonomi, dan lain sebagainya. Fenomena kekerasan semakin marak dalam kehidupan bermasyarakat. Sebagian orang dapat mengatasi pengalaman akan kekerasannya, namun sebagian besar mencari solusi atau mencari jalur hukum untuk memperoleh penyelesaian yang lebih baik.

Asma Nadia merupakan salah satu penulis perempuan terbaik yang dimiliki oleh Indonesia dan karya-karyanya pun banyak menceritakan tentang perempuanperempuan Indonesia yang tangguh. Novel merupakan hasil cipta karya sastra, yang juga sebagai cerminan dari masyarakat salah satunya adalah mengenai persoalan perempuan (Sulaeman dkk., 2020). Novel-novel Asma Nadia menggambarkan tingkah laku, sifat, masalah perempuan yang ada dalam kehidupan nyata.

Djajanegara (2003:30) menyatakan dalam pandangan masyarakat patriarki tumbuh dan mengakar sebuah konsep bahwa perempuan yang ideal adalah perempuan yang harus rela mengalah. Sifat yang tercermin dari konsep itu adalah perempuan yang menjaga kesadaran serta kemurnian mereka, berpikir pasif, dan menyerah, serta rajin mengurus rumah tangga atau domestisitas.

Penelitian ini bertujuan untuk memperoleh pemahaman yang mendalam terhadap kekerasan dan sikap perempuan dalam menerima kekerasan dalam novel Cinta Dua Kodi karya Asma Nadia. Peneliti memilih novel Cinta 2 Kodi karya penulis Ama Nadia sebagai sumber data penelitian ini. Novel-Novel Asma Nadia memuat kisah menyentuh dan menggetarkan tentang perjuangan perempuan, seorang istri, sekaligus ibu dalam menghadapi berbagai prahara 
rumah tangga. Sebagian besar cerita yang diuraikan pada novel adalah kisah nyata, bahkan novel Cinta 2 Kodi sepenuhnya mengangkat kisah nyata seorang Ika Kartika pengusaha perempuan Indonesia yang berjuang membangun usaha dan juga keluarganya.

Rosita (2018) sudah meneliti novel Cinta 2 Kodi pada aspek pendidikan karakter yang terdapat dalam novel tersebut. Pendidikan karakter yang dimunculkan dalam novel Cinta 2 Kodi yaitu religius, jujur, kerja keras, disiplin, kreatif, mandiri, cinta tanah air, demokrasi, rasa ingin tahu, bersahabat, menghargai prestasi, peduli sosial, gemar membaca, dan tanggung jawab. Selain itu dari hasil penelitian ini yang bisa diteladani dari kisah dalam novel ini yaitu dalam meraih sebuah kesuksesan diperlukan kesabaran, kedisiplinan, semangat, dan kerja keras yang harus melalui proses panjang.

Kemudian, novel karya Asma Nadia yang lain yaitu novel Bunda: Kisah Cinta 2 Kodi sudah pernah diteliti oleh Udasmoro (2017) tentang reproduksi Womanhood yang menghasilkan temuan penelitian berupa sastra sering kali dianggap sebagai titik balik narasi dari tokoh perempuan yang bergerak dari suatu narasi yang terbuka dan bersifat self autonomous kembali ke beberapa sisi subordinatif perempuan. Hasil penelitian ini juga menyoroti tentang karakter perempuan yang hebat dan kuat, tetapi tidak khusus melihat aspek kekerasan terhadap perempuan. Dengan demikian, dari beberapa penelitian relevan menunjukkan bahwa bentuk kekerasan dan sikap perempuan dalam menerima kekerasan dalam novel Cinta 2 Kodi karya Asma Nadia, belum ada yang meneliti.

\section{B. Metode Penelitian}

Dalam penelitian ini digunakan pendekatan kualitatif dengan metode analisis isi. Dimana peneliti mendeskripsikan secara sistematis, faktual, dan akurat mengenai fakta-fakta dan hubungan kausal fenomena yang diteliti khususnya tentang bentuk kekerasan dan sikap perempuan dalam menerima kekerasan dalam novel Cinta 2 Kodi karya Asma Nadia. Data yang ada berupa pencatatan dokumen yang terurai dalam bentuk kata-kata, kalimat-kalimat, bukan dalam angka-angka. Eriyanto (2011) menjelaskan bahwa analisis isi bertujuan 
mengungkapkan berbagai informasi dengan menganalisis dan memahami teks sehingga ditemukan makna yang sebenarnya.

Penelitian ini menggunakan bentuk penelitian kualitatif. Bentuk ini tidak memaparkan bentuk angka-angka perhitungan, tetapi menampilkan analisis data yang diperoleh. Alasan peneliti dalam menggunakan bentuk penelitian ini karena lebih sesuai dengan objek penelitian yang akan diteliti. Bogdan \& Taylor dalam Moleong (2010) mengatakan bahwa penelitian kualitatif merupakan prosedur penelitian yang menghasilkan data deskripsi berupa kata-kata tertulis atau lisan dari orang-orang dan perilaku yang diamati. Kedudukan peneliti dalam penelitian ini sebagai perancang, pengumpul data, penganalisis, penafsir data, dan pelaporan hasil penelitian. Dalam hal ini, perlu membaca dengan aktif, terus menerus, mengamati, dan mengidentifikasi satuan-satuan yang sesuai dengan tujuan penelitian, kemudian menafsirkan dan melaporkan hasilnya.

Teknik pengumpulan data dalam penelitian menggunakan teknik dokumentasi berupa novel Cinta 2 Kodi karya Asma Nadia. Novel ini dipublikasi oleh AsmaNadia Publishing House pada tahun 2017 dengan tebal 378 halaman. Instrumen utama dalam penelitian adalah peneliti sendiri dibantu dengan tabulasi data penelitian yang memuat interpretasi tentang bentuk kekerasan dan sikap tokoh perempuan terhadap kekerasan yang dialami dalam novel Cinta 2 Kodi karya Asma Nadia.

Di dalam penelitian ini, peneliti mengembangkan tiga langkah (prosedur) penelitian dan langkah analsis data berdasarkan metode analisis isi, yaitu:

(1) Pengadaan data yang terdiri dari:

a. Menentukan karya yang dijadikan objek material penelitian, yaitu novel karya Asma Nadia yang berjudul Cinta 2 Kodi.

b. Menentukan masalah pokok penelitian, yaitu masalah kekerasan terhadap perempuan dalam novel Cinta 2 Kodi.

c. Menentukan tujuan penelitian. Tujuan yang hendak dicapai dalam penelitian ini adalah untuk mendeskripsikan kekerasan terhadap perempuan dalam novel "Cinta 2 Kodi” karya Asma Nadia. 
(2) Melakukan deskripsi data dengan membuat tabulasi data dan pengkodingan data bentuk kekerasan dan sikap sikap tokoh perempuan terhadap kekerasan yang dialami dalam novel Cinta 2 Kodi karya Asma Nadia.

(3) Seleksi data dengan melakukan pemilihan data peristiwa novel yang mengandung kekerasan terhadap tokoh perempuan dan melakukan klasifikasi data.

(4) Melakukan interpretasi data berdasarkan masalah penelitian, untuk selanjutnya menyimpulkan hasil analisis dan menyusun laporan penelitian.

\section{Hasil Penelitian dan Pembahasan}

\section{Hasil Penelitian}

a. Bentuk Kekerasan pada Novel Cinta 2 Kodi Karya Asma Nadia

Pada novel Cinta 2 Kodi karya Asma Nadia ditemukan bentuk kekerasan psikis pada tokoh perempuan.

1) Aryani

Kekerasan psikis dialami oleh Aryani. Terlihat ketika Aryani tengah hamil tua dan masih tetap harus kerja keras mengajar, mengajak suaminya untuk pulang bersamanya, namun suaminya Bagja menolak dan membiarkan Aryani untuk pulang sendiri dalam keadaan hujan (Nadia, 2017). Data berikut mencerminkan bentuk kekerasan psikis yang dialami oleh Aryani.

"Perempuan berkerudung itu tersungkur. Perutnya menghunjam tanah basah.

Tubuh terguling jauh meninggalkan payung yang sejak tadi terlepas." (C2K. 42).

Kekerasan psikis terhadap Ariyani lainnya yaitu masih dilakukan oleh suaminya. Bagja sering meluapkan kemarahan terhadap Aryani bahkan karena hal kecil sekalipun. Dapat dilihat pada kutipan berikut.

\footnotetext{
"Ketika Bagja sedang asyik dengan kendaraan kesayangan, tak ada yang boleh mengganggu. Aryani bahkan berjuang agar Suci tidak rewel atau teriak-teriak. Salah sedikit maka akan kena teguran." (C2K. 110).

"Kemarahan lelaki itu suatu hari, hanya karena Aryani alpa membawa sedotan untuk kocokan arisan, yang bisa dengan mudah dibeli di toko terdekat."

(C2K. 111).
}

Kemarahan demi kemarahan diterima oleh Aryani dengan penuh kesabaran. Rasa waswas setiap kali suami menginjakkan kaki di rumah dirasakan oleh 
Aryani, siksaan batin yang harus terus dihadapinya (Nadia, 2017). Dapat dilihat pada kutipan berikut.

\begin{abstract}
"Mama selalu memastikan tak satu hal pun akan memicu kemarahan suami. Makanan tersedia apik di atas meja, rumah tertata rapi. Anak-anak dipastikan sudah mengerjakan PR. Beberapa rutinitas yang harus diselesaikan sebelum Papa pulang." (C2K. 210).

"Begitu pun, Bagja masih saja menemukan celah untuk meluapkan emosi. Makanan yang terlalu asin, anak yang belajar sambil bercanda, sampah yang masih terserak. Ada saja." (C2K. 210).
\end{abstract}

Kekerasan psikis lainnya yang dialami oleh Aryani yaitu ketika suaminya membuat surat kematian dirinya demi untuk menikah lagi. Dapat dilihat pada kutipan berikut.

"Kartika menelusuri informasi itu sampai akhirnya menemukan fakta, surat kematian dibutuhkan sebagai syarat menikah." (C2K. 211).

\title{
2) Kartika
}

Kekerasan psikis yang dialami oleh Kartika dalam novel ini yaitu, ketika suaminya menyampaikan bahwa ibunya yang sedang sakit meminta untuk menceraikannya. Dapat dilihat pada kutipan berikut.

\footnotetext{
"Ibu minta Uda menceraikan kamu."

"Tangis Kartika pecah. Farid meraih istrinya, merengkuh dalam dekapan erat. Berusaha mengusir kebekuan yang tiba-tiba singgah. Kartika ingin menepis, tapi kekuatan seolah dirampas sempurna. Sedemikian rendahkah dia hingga tak layak menjadi pendamping laki-laki itu?" (C2K. 223-224).
}

Selain meminta untuk menceraikannya, Farid juga menyampaikan bahwa walaupun ibu telah mengetahui kehamilan Kartika, namun ibu tetap bersikeras meminta Farid untuk menceraikan bahkan sekaligus menggugurkan kandungan Kartika (Nadia, 2017). Hal tersebut tentu menimbulkan tekanan batin pada diri Kartika. Pernikahan yang baru saja mereka mulai, hanya karena adat harus berakhir. Dapat dilihat pada kutipan berikut.

\footnotetext{
"Suami berlutut, menadahkan maaf dan ampun, untuk sebuah permintaan yang mustahil dipenuhi."

"Ibu minta kamu menggugurkan kandungan." (C2K. 228).

"Beberapa menit berikutnya, sang suami menyebut sebuah klinik yang sering mereka lewati. Kartika sulit memercayai bagaimana Farid bisa memberikan deskripsi detail tempat yang dimaksud." (C2K. 228).
}

Silampari Bisa: Jurnal Penelitian Pendidikan Bahasa Indonesia, Daerah, dan Asing Vol. 3, No. 2, 2020 
"Demi apa pun, haruskah ia mengorbankan makhluk mungil dalam kandungan demi memenuhi permohonan suami, dan memudahkan jalan bagi laki-laki itu untuk menjadi anak berbakti bagi ibunya?" (C2K. 230).

\section{b. Sikap Perempuan Menerima Kekerasan dalam Novel Cinta Dua Kodi Karya} Asma Nadia

1) Aryani

Sikap Aryani dalam menerima kekerasan sikap suaminya. Setelah bertahun-tahun bersabar dan menerima perlakuan suaminya Aryani akhirnya memutuskan untuk mengakhiri pernikahan. Dapat dilihat pada kutipan berikut.

"Seluruh anggota keluarga duduk mengelilingi meja makan. Raut perempuan yang melahirkan anak-anaknya ke dunia terlihat tanpa riak. Kalimatnya pun teratur. Namun permintaan yang diajukan membuat setiap orang terbelalak. Mama menuntut cerai." (C2K. 213).

"Sesudah semua anak menempuh hidup baru, Mama lantas mengajukan keputusan mengagetkan. Inilah batas kesabaran yang sanggup diberikannya." (C2K. 214).

2) Kartika

Sikap Kartika dalam menerima kekerasan psikis ia tetap bertahan dengan kesabaran mempertahankan pernikahan dan bayi yang dikandungnya. Kartika berjuang keras menyelamatkan kehidupan keluarga dan rumah tangganya demi sebuah harapan, impian dan cintanya kepada suami dan anak-anaknya. Dapat dilihat pada kutipan berikut.

"Kartika mendadak diliputi kerlip keriangan. Aneka rancangan mukena kecil bernuansa imut berlesatan. Dadanya berdebur kencang dengan serangan ilham dari-Nya yang muncul di saat ia mengira sudah menemui jalan buntu. Sebuah keyakinan dan semangat mengeras, insya Allah mereka mampu bertahan." (C2K. 332).

"Memasuki bulan Ramadhan, permintaan mukena meningkat pesat. Perempuan yang semangatnya menggelegak, mulai memasok mukena ke Tanah Abang, Senen, Mayestik, Rawamangun, Jatinegara, dan semua rekan bisnis yang pernah dirintis selain membuka pasar baru." (C2K. 339).

\section{Pembahasan}

Berdasarkan data yang telah dianalisis pada novel Cinta 2 Kodi karya Asma Nadia, bentuk kekerasan yang dialami oleh tokoh perempuan yaitu terdapat bentuk kekerasan psikis. Kekerasan yang terjadi pada tokoh perempuan merupakan bentuk ketidakadilan gender. Kekerasan atau penyiksaan terhadap kaum perempuan dapat berupa kekerasan fisik, psikis, maupun kekerasan 
seksual dan hal ini hanya ditemukan kekerasan psikis dalam novel Cinta 2 Kodi. Diungkapkan Fakih (2013) kekerasan yang bersifat fisik yaitu pemerkosaan, persetubuhan antar anggota keluarga (incest), pemukulan dan penyiksaan, bahkan yang lebih sadis lagi pemotongan alat genital perempuan. Kekerasan dalam bentuk nonfisik yang sering terjadi yaitu pelecehan seksual, menyebabkan ketidaknyamanan bagi perempuan secara emosional.

Berdasarkan temuan hasil penelitian kekerasan psikis yang dialami oleh Aryani yaitu ketika dia mengira ujian terberat dimulai ketika menyadari perubahan Bagja hanyalah sementara, sekadar demi mewujudkan keinginan menikahi dirinya. Namun, Bagja benar-benar tidak memperdulikannya. Terlihat ketika Aryani tengah hamil tua dan masih tetap harus mengajar mengajak Bagja untuk pulang bersamanya, namun Bagja menolak dan membiarkan Aryani untuk pulang sendiri dalam keadaan hujan. Aryani terjatuh, perutnya menghunjam tanah basah, tubuhnya terguling jauh. Aryani tak mampu bergerak. Kejadian tersebut menyebabkan bayi yang dilahirkan Aryani mengalami gangguan fisik. Menurut neurolog, ada saraf tulang belakang yang putus, sehingga bayi tidak bisa tumbuh kembang dengan normal. Keadaan ini pun masih tetap Bagja menyalahkan Aryani, Bagja menganggap hal ini terjadi karena kecerobohan Aryani.

Sepanjang menjalani rumah tangga, Aryani mengalami kekerasan psikis yang dilakukan oleh suaminya. Seiring bertambah usia anak-anak kesibukan melakukan pekejaan rumah tangga semakin meningkat. Suami tidak pernah mendukungnya. Kekuatan terkuras membuat Aryani jatuh sakit, penyakit yang tidak terdeteksi akibat stres berkepanjangan.

Kekerasan psikis juga dialami oleh tokoh perempuan lainnya yaitu Kartika. Ketika suaminya menyampaikan bahwa ibunya yang sedang sakit meminta untuk menceraikannya. Selain meminta untuk menceraikannya, Farid juga menyampaikan bahwa walaupun ibu telah mengetahui kehamilan Kartika, namun ibu tetap bersikeras meminta Farid untuk menceraikan bahkan sekaligus menggugurkan kandungan Kartika. Hal tersebut tentu menimbulkan tekanan batin pada diri Kartika. Pernikahan yang baru saja mereka mulai, hanya karena adat harus berakhir. Sejak awal pernikahan antara Kartika dan Farid tidak disetujui oleh 
keluarga Farid hanya karena masalah adat yang bertentangan dengan keluarga Kartika.

Sikap Aryani menerima kekerasan psikis yang dialaminya. Setelah bersabar dalam menghadapi perlakuan suaminya Aryani memutuskan untuk meminta cerai kepada Bagja. Perpisahan terjadi setelah Aryani mengantar tiga buah hatinya ke jenjang pernikahan. Kartika sebagai perempuan yang tidak mudah menyerah dan pekerja keras. Sikap seorang perempuan bernama Kartika. la berjuang keras menyelamatkan kehidupan keluarga dan rumah tangganya demi sebuah harapan, impian dan cintanya kepada suami dan anak-anaknya. Keberanian untuk memulai sebuah bisnis baju muslim anak-anakk sesuatu yang belum ia pahami sama sekali, serta keberanian menerima kenyataan pahit bahwa suami yang selama ini menjadi teladan dan tulang punggung keluarga memutuskan untuk menjadi ayah rumah tangga karena tempat suaminya bekertja termasuk yang pertama kali tumbang ketika krisis moneter melanda Indonesia. Nilai karakter sabar, ikhlas, kerja keras, dan berani yang dilakukan oleh tokoh perempuan dalam novel Cinta 2 Kodi karya Asma Nadia merupakan wujud dari sebuah karya seutuhnya. Hal ini sesuai dengan pendapat (Wellek \& Warren, 1976) bahwa karya sastra harus memiliki nilai dan manfaat bagi pembacanya.

\section{Simpulan dan Saran}

Berdasarkan penelitian yang telah dilakukan, peneliti menemukan tindakan kekerasan psikis terhadap tokoh perempuan yaitu Aryani dan Kartika. Kemudian, sikap yang dilakukan oleh tokoh perempuan dalam menghadapi kekerasan psikis yaitu sabar, ikhlas, kerja keras, dan berani. Kekerasan psikis yang dilakukan oleh suami Aryani menyebabkan Aryani mengalami penyakit yang tidak terdeteksi akibat stres berkepanjangan. Budaya patriarki membuat lelaki tidak terdidik untuk terampil dalam menyelesaikan pekerjaan rumah tangga. Dalam budaya ini, pekerjaan rumah tangga hanya pantas dilakukan perempuan. Aryani mengalami kekerasan psikis bekerja jauh lebih keras dan harus ekstra memastikan kebutuhan suami memperoleh waktu dan kenyamanan di rumah. 
Hasil temuan penelitian direkomendasikan untuk pembelajaran sastra di perguruan tinggi khususnya pada Mata Kuliah Kajian Sastra. Hasil penelitian ini juga memiliki keterlibatan yang erat dengan pembelajaran bahasa dan sastra Indonesia di sekolah, yang mengandung standar kompetensi berupa memahami pembacaan novel. Kegiatan menganalisis novel merupakan pelatihan bagi peserta didik meningkatkan keterampilan berbahasanya. Dalam novel karya Asma Nadia menampilkan kisah perjuangan perempuan sehingga dapat dijadikan bahan pembelajaran sastra di sekolah.

\section{Daftar Pustaka}

Djajanegara, S. (2003). Kritik Sastra Feminis: Sebuah Pengantar. Jakarta: Gramedia Pustaka Utama.

Eriyanto. (2011). Analisis Isi: Pengantar Metodologi untuk Penelitian IImu Komunikasi dan IImu-ilmu Sosial Lainnya. Jakarta: Kencana.

Fakih, M. (2013). Analisis Gender dan Transformasi Sosial. Yogyakarta: Pustaka Pelajar.

Febriany, I. S. (2016). Kekerasan terhadap Perempuan dan Anak Ekologi Keluarga sebagai Pencegahan Kekerasan terhadap Perempuan dan Anak. Jurnal Harkat: Media Komunikasi Gender, 12(1), 29-36. doi:10.15408/harkat.v12i1.7577

Fitriani, D. (2019). Kekerasan terhadap Perempuan dalam Novel Bidadari Hitam Karya T.I. Thamrin. Jurnal Sains Riset, 7(3). doi:10.47647/jsr.v7i3.17

Galistya, T. M. (2019). Kekerasan terhadap Perempuan dan Perceraian dalam Perspektif Pemberdayaan Perempuan. Jurnal Dinamika Sosial Budaya, 21(1), 19. doi:10.26623/jdsb.v21i1.1500

Moleong, L. J. (2010). Metodologi Penelitian Kualitatif. Bandung: Remaja Rosdakarya.

Nadia, A. (2017). Cinta 2 Kodi. Jakarta: AsmaNadia Publishing House.

Noermanzah, N. (2017). Plot in a Collection of Short Stories "Sakinah Bersamamu" Works of Asma Nadia with Feminimism Analysis. Humanus, 16(1), 27-28. doi:10.24036/jh.v16i1.7015 
Ritzer, G. \& Goodman, D. J. (2012). Teori Sosiologi Modern. Diterjemahkan oleh Alimandan. Jakarta: Ghalia Indonesia.

Rokhmansyah, A., Valiantien, N. M., \& Giriani, N. P. (2018). Kekerasan terhadap Perempuan dalam Cerpen-Cerpen Karya Oka Rusmini. LITERA, 17(3). doi:10.21831/Itr.v17i3.16785

Rosita, F. Y. (2018). Pendidikan Karakter Dalam Novel Cinta 2 Kodi Karya Asma Nadia. Alayasastra, 14(1), 55. doi:10.36567/aly.v14i1.197

Santoso, A. (2011). Bahasa Perempuan. Jakarta: Bumi Aksara.

Sulaeman, A., Goziyah, Purawinangun, I.A., Noermanzah. (2020). Social Value in the Novel Hatta: Aku Datang karena Sejarah by Sergius Sutanto as Teaching Materials in Teaching Literature in Schools. International Journal of Scientific and Technology Research, 9(3). 611. http://www.ijstr.org/paperreferences.php?ref=|JSTR-0320-32332

Udasmoro, W. (2017). Reproduksi Womanhood dalam Novel Bunda: Kisah Cinta 2 Kodi Karya Asma Nadia. Adabiyyāt: Jurnal Bahasa dan Sastra, 1(2), 182. doi:10.14421/ajbs.2017.01203

Wellek, R. \& Warren, A. (1976). Theory of Literature. USA: Penguin University Books.

Werdiningsih, Y. K. (2016). Kekerasan terhadap Tokoh Utama Perempuan dalam Novel Kinanti Karya Margareth Widhy Pratiwi. ATAVISME, 19(1), 102-115. doi:10.24257/atavisme.v19i1.41.102-115 